\title{
THE EFFECT OF HEAD'S LEADERSHIP AND NURSES' JOB MOTIVATION ON NURSING PERFORMANCE IN THE HOSPITAL INPATIENT ROOM
}

\author{
Efek Kepemimpinan dan Motivasi Kerja Terhadap Kinerja Perawat di \\ Ruangan Rawat Inap Rumah Sakit
}

${ }^{*}$ Budi Hartono ${ }^{1,2}$, Alfi Hidayati', Tri Kurniati', Nur'aina Basir ${ }^{1}$

${ }^{1}$ Department of Public Health, STIKes Hang Tuah Pekanbaru, Indonesia

${ }^{2}$ Department of Public Health, Faculty of Medicine and Health,

Muhammadiyah Jakarta University, Indonesia

${ }^{*}$ Correspondence: budi.hartono@htp.ac.id

\begin{abstract}
Background: The fluctuated patient satisfaction level shows the need to improve nursing performance. Several factors that can improve nursing performance include leadership, job motivation, management, and environment. Leadership and job motivation become fundamental aspects of improving employee performance. Aim: This study analyzed the role of the head's leadership and nurses' job motivation on nursing performance in the Indonesian Red Cross Hospital Bogor's inpatient room.

Methods: This study sampled 150 nurses in the inpatient room of the Indonesian Red Cross Hospital Bogor using the incidental random sampling technique. This study employed a path analysis with three variables: the head's leadership and job motivation as exogenous variables and nursing performance as an endogenous variable.

Results: Leadership of the heads of the inpatient room could increase job motivation and nursing performance. Conclusion: Managers' leadership and job motivation could partially and simultaneously affect the level of nurses' performance. The Indonesian Red Cross Hospital Bogor could provide regular training to every head of the room to enhance their leadership and nurses' job motivation.
\end{abstract}

Keywords: leadership, job motivation, nurses' work performance.

\section{ABSTRAK}

Latar Belakang: Tingkat kepuasan pasien yang fluktuatif menunjukkan kinerja perawat perlu ditingkatkan. Beberapa faktor yang dapat meningkatkan kinerja perawat adalah kepemimpinan, motivasi kerja, manajemen dan lingkungan. Kepemimpinan dan motivasi kerja merupakan aspek yang mendasar dalam meningkatkan kinerja karyawan.

Tujuan: Penelitian ini menganalisis peran kepemimpinan dan motivasi kerja terhadap kinerja perawat yang ada di ruangan rawat inap di Rumah Sakit Palang Merah Indonesia Bogor.

Metode: Penelitian ini memilih sampel semua perawat di ruangan rawat inap sejumlah 150 orang dengan menggunakan teknik pengambilan sampel acak insidentil. Analisis data menggunakan metode analisis jalur dengan tiga variable yaitu peran kepemimpinan dan motivasi kerja sebagai variabel eksogen dan kinerja perawat sebagai variabel endogen.

Hasil: Hasil pengujian hipotesis tersebut pada dasarnya berimplikasi bahwa peran kepemimpinan kepala ruangan dapat meningkatkan motivasi kerja perawat serta kinerja perawat dapat menjadi lebih baik.

Kesimpulan: Secara parsial maupun simultan, peran kepemimpinan kepala dan motivasi kerja dapat mempengaruhi tingkat kinerja dari para perawat. Rumah Sakit Palang Merah Indonesia Bogor dapat memberikan pelatihan rutin kepada setiap kepala ruangan untuk meningkatkan peran kepemimpinan dan motivasi kerja perawat.

Kata kunci: kepemimpinan, motivasi kerja, kinerja perawat. 


\section{INTRODUCTION}

To provide effective and efficient services to the community, public service providers should have excellent performance. Government-owned or private-public service providers have to possess integrity, professionalism, neutrality, and freedom from any pressure and Corruption, Collusion, and Nepotism (KKN) (Hayat, 2014). Public health service providers specifically have to yield optimal performance to serve the community. Humans are the driving aspect and determine the success of an organization or institution. Notably, public health service providers must have proper assessment or evaluation and get attention from leaders. The Law of Republic of Indonesia No. 36 of 2014 concerning Health Workers stated that health workers have an essential role in health services. Employees, or particularly health workers, are essential for every organization to effectively and efficiently achieve their goals. An organization expects its members not only to be competent, skilled, or capable of carrying out a task but also to be willing to work hard and achieve optimal results for an organization or institution (Indriyati and Hayat, 2015).

The Law of Republic of Indonesia No.44 of 2009 defines hospitals as an integral part of the entire health care system. The Indonesian Ministry of Health outlines that public hospitals are in charge of efficiently and effectively carrying out health services by prioritizing healing and recovery in a harmoniously integrated manner to improve, prevent, and carry out referrals. It is expected that hospitals can carry out affordable quality health services and optimal results to satisfy the customers.

The on-going hospital service system has to be reviewed to anticipate global competition in this globalization era. It should meet the community needs due to changes in the epidemic, the development of science and technology, and the socioeconomic structure. Public scrutiny and criticism, mainly dissatisfaction with health services, become one of the hospitals' problems. Therefore, health workers' performance is the key to serve patients more efficiently and effectively and with productive and excellent services (Gunawan, 2016).

If health workers do not provide excellent services, they will be detrimental to patients and other parties associated with various administrative matters (Rakhmawati, 2008). For example, slow and convoluted new patient registration will insecure patients' data. However, excellent public service will be challenging to achieve when health workers cannot improve their performance.

The success of public services at the Indonesian Red Cross Hospital Bogoris is inseparably related to health workers' productivity and performance. The percentages of hospital visitor satisfaction levels within 3 years were $84.66 \%$ (2013), $83.55 \%$ (2014), and $82.29 \%$ (2015). While, the Bed Occupancy Rates (BOR) was at $77.80 \%$ (2014) and $65.71 \%$ (2015). The data show that the hopsital's patient satisfaction level decreased due to decreased service performance levels. Gunawan (2016) states that health workers' performance strongly influences service performance.

The decrease in health workers' performance seems not to stand alone. It turns out to be correlated or influenced by various factors. Presumably, the role of head's leadership and employee job motivation can be considered as two dominant factors that possibly had a positive effect on the health workers' performance at the hospital. This assumption is based on some propositions.

First, how far the role of leadership between the leaders and staff influences achieving common goals. Leadership can 
also be seen in the process of cooperation between leaders and staff. It can respond to employee performance directly or indirectly. The 2011-2015 hospital visitor satisfaction level shows that leadership can certainly positively affect the health workers' performance at the hospital.

Second, job motivation is a driving force to improve health workers' performance. In a functional context, job motivation can also have a positive effect on health workers' performance. After being studied in-depth and considering various factors, this study assumes that head's leadership and nurses' job motivation may positively affect the health workers' performance. Organizations that succeed in achieving their goals and fulfilling their social responsibilities will significantly depend on managers or leaders. Leaders' quality becomes the most important factor in the success or failure of both business-oriented and public organizations.

This study lay upon the assumption that the hospital administration focuses on improving health workers' performance to serve better services. It is unclear whether or not problems in resources apparatus caused a decrease in patient satisfaction level. It is important to identify means of providing excellent services from the perspective of leadership and job motivation.

Leadership style is a method used by a leader to influence the behavior of others. A leader should have specific characteristics, understand leadership characteristics, and have three leadership components, such as leader, followers, and situation. Paramita (2011) mention several effective leadership styles in an organization: charismatic, authoritarian, democratic, and moral. While work ethic contributes relatively small but is still significantly used as a dimension that may affect an organization's performance. However, leadership and work ethic should simultaneously give a relatively large and significant contribution to improving employee performance and organizational development. The research conducted by Paramita (2011) used a quantitative approach, as this present study did. Their study involved leadership style and work ethic that presumably affect performance, while this present study researched leadership and job motivation. The differences as mentioned above and similarities became references in this present study to understand how they structured the research variables and how leadership influences performance.

Warella, Rachmawati and Hidayat (2006) found a mutual relationship between employee job motivation and performance. The higher the job motivation, the higher the employee performance level. While they also discovered the same results in leadership and employee performance variables. Moreover, they found a significant relationship between job motivation, workability, leadership styles, and employee performance. Another study conducted by Tri Sasongko (2016) found that leadership style negatively influences employee performance ( $\mathrm{t}$-value $=2.756$ ), but job motivation does not affect it. Referring to other previous iesstudies, this study brought the importance of analyzing the effect of leaders' leadership and employee job satisfaction on their performance. The fluctuated patient satisfaction level at the Indonesian Red Cross Hospital Bogor shows inoptimal nursing performance. According to the Head of the Medical Records Division, a decrease in inpatient visits and poor services by inpatient nurses indicate a lack of performance. The outpatient satisfaction level in 2014 and 2015 decreased compared to 2013. Moreover, a decrease in BOR occurred in the same year.

Based on the background of the issue, this study only discussed factors that might affect employee performance at the 
Indonesian Red Cross Hospital Bogor. More comprehensive findings might come from identifying all possibly affecting factors, but it is the limitation of this study that cannot research all at the same time. This study only picked leadership and job motivation, which effect on employee performance was in question.

\section{METHODS}

This study used a quantitative method and path analysis, which is mainly used for (1) explaining the study's phenomenon or problem (Kuncoro, 2007). This study analyzed the effect of leadership and job motivation (X1 and X2) on nurse's performance $(\mathrm{Y})$; (2) predicting the value of the dependent variable $(Y)$ based on the value of the independent variables $(\mathrm{X})$; $(3)$ determining factors that identify the effect of the independent variable $(\mathrm{X})$ on the dependent variable $(\mathrm{Y})$; (4) exploring the mechanism (pathways) of the effect of the independent variable $(X)$ on the dependent variable $(Y)$.

According to Covey (2005), leadership is a proactive effort to strengthen primary value and potency from people around us through four dimensions. These dimensions were developed into 12 indicators in the questionnaire. First, the role model was defined from (1) attitude, (2) nature, and (3) behavior. Second, pioneer was assessed from (4) organizational strategy, (1) organizational goals, and (2) organizational vision. Third, the coordinator was reviewed from (1) work systems development, (2) work systems management, and (3) work systems directives. Lastly, the advocator was broken down into (1) work focus, (2) work methods, and (3) teamwork.

This study also adopted the hierarchy of needs by Maslow (2013). The job motivation variable had five dimensions: physiological needs, security needs, social needs, appreciation needs, and self- actualization needs. These dimensions were then developed into twelve indicators in the questionnaire items. Physiological needs were measured from (1) life needs, (2) service, and (3) entertainment. Security needs were broken down into (1) internal situation and (2) external situation. In addition, social needs were seen from (1) togetherness and (2) teamwork. Appreciation needs were defined based on (1) leader appreciation to staff, (2) staff appreciation to leaders, and (3) appreciation among staff. Self-actualization needs were described from (1) self-image and (2) work performance.

There were twenty-one dimensions for staff performance variable, such as clarity, assistance, incentive, evaluation, accuracy, and social life. These dimensions consisted of 14 indicators. Clarity was viewed from (1) understanding about tasks, (2) perception, (3) regulation, and (4) information. The assistance dimension consisted of (1) individual support, (2) group support, and (3) organization support. Incentive dimension was viewed from (1) salary, (2) incentive, (3) compensation, and (4) bonus. The evaluation dimension consisted of (1) assessment, (2) training, (3) supervision, and (4) counseling. Accuracy dimension included (1) individual task, (2) group task, and (3) organization task. Last but not least, the social life dimension was assessed from (1) benefit, (2) teamwork, and (3) loss.

The questionnaires showed 0.159 validity, and the reliability scores on leadership, motivation, and performance variables were $0.912,0.785$, and 0.897 , respectively. The results concluded that the questionnaires used were valid and reliable. Data collection was conducted through self-administered questionnaires from May to June 2016 and then analyzed using SPSS software.

This study's unit of analysis was inpatient rooms at the Indonesian Red 
Cross Hospital Bogor, located at Jl. Raya Pajajaran No. 80 Bogor. The population was 241 nurses in 12 inpatient rooms. The researchers first obtained permission from respondents during the data collection by distributing informed consent, anonymity, confidentiality, and freedom sheet. According to Sugiyono (2011), samples taken from the population must be truly representative. This study calculated the exact number of samples using the Slovin formula (Bungin and Burhan, 2005). The final samples obtained were 150 nurses. It lay upon the selected confidence level of $95 \%$, the alpha significance level of $5 \%$, and the $r$ table of 0.159 .

The random sampling was used when the researchers selected the respondents they met during the data collection (Sugiyono, 2016). To be considered the samples, the respondents should be permanent inpatient nurses willing to be respondents. Meanwhile, inpatient nurses who were on leave or sick and worked for less than one year were not selected. The total amount of the sample fraction was adjusted with the number of units, while the fi value was calculated through a random sampling method.

There were nineteen respondents in Dahlia Room, nine in VK Room, fourteen in Orchid Room, sixteen in Rose Pavilion, twelve in Jasmine Pavilion, and eleven in Flamboyant Pavilion. Additionally, there were ten respondents in Allamanda Pavilion, eleven in Aster Room, twelve in Magnolia Room, fourteen in Gardenia Room, eleven in Chrysanthemum Room, and eleven in Ixora Room.

\section{RESULTS AND DISCUSSION}

\section{Respondents'Characteristics}

Respondents' characteristics include age, gender, latest education, work period, and social status. Table 1 shows that the majority of respondents were female (72\%) and had Associate Degrees (Diploma III)

The Effect of...
(91.3\%). Most of the respondents were married $(67.3 \%)$. Some of them were aged around 31 to 40 years (30.7\%). Nearly half have worked for more than ten years $(45.3 \%)$.

\section{Distribution of Respondents' Response}

As many as $63.5 \%$ of respondents agreed and strongly disagreed with the role model's function to improve staff performance. Covey (2005) asserts the role model is a characteristic that drives someone to be a leader. This study also obtains $44 \%$ in total disagreed with the role of pioneer in improving staff performance. Moreover, $89.3 \%$ agreed that the coordinator dimension might improve staff performance.

A total of $77.3 \%$ of respondents agreed that the advocator dimension also may increase staff performance as Covey (2005) states that empowering a leader's skill is an internal potential that can be inherited to each staff. Table 2 shows that $54.9 \%$ in total did not agree that the dimension of the physiological need may improve staff performance. However, $73.2 \%$ of the respondents agreed that security needs may be the one that may improve staff performance.

There were $65.5 \%$ of respondents agreed that appreciation needs may make employees perform well. Besides, $77 \%$ of the respondents positively responded towards the function of self-actualization in improving their performance. It is also relevant to the hierarchy theory by Maslow (2013). In terms of staff performance itself, $65.2 \%$ agreed that tasks' clarity may encourage staff to perform better at work.

Moreover, $67.1 \%$ of the respondents agreed that the assistance dimension was thought to improve task performance. Improvement in task performance also has something to do with the incentive, as $78.2 \%$ have said in the questionnaire. As many as $70.5 \%$ of the respondents also agreed that the evaluation dimension may 
encourage staff to perform well. The table also shows that $77.7 \%$ agreed that the validity dimension may also enhance staff performance, and $74.4 \%$ of the respondents thought employee social life is possible to improve their performance.

Table 1. Distribution of Respondents' Characteristics.

\begin{tabular}{|c|c|c|c|c|}
\hline Confounding Variables & Frequency & Percentage & Validity Score & $\begin{array}{l}\text { Cumulative } \\
\text { Frequency }\end{array}$ \\
\hline \multicolumn{5}{|l|}{ Gender } \\
\hline Male & 42 & 28 & 2.8 & 2.8 \\
\hline Female & 108 & 72 & 7.2 & 100.00 \\
\hline Total & 150 & 100 & & \\
\hline \multicolumn{5}{|l|}{ Education } \\
\hline Senior High School & 2 & 1.3 & 1.3 & 1.3 \\
\hline Diploma III/Associate & 137 & 91.3 & 91.3 & 92.7 \\
\hline Degrees III & 11 & 7.3 & 7.3 & 100.00 \\
\hline Bachelors & 150 & 100 & & \\
\hline \multicolumn{5}{|l|}{ Total } \\
\hline \multicolumn{5}{|l|}{ Work Period } \\
\hline$<1$ year & 19 & 12.7 & 12.7 & 12.7 \\
\hline $1-3$ years & 27 & 18.0 & 18.0 & 30.7 \\
\hline 3-6years & 23 & 15.3 & 15.3 & 46.0 \\
\hline $6-10$ years & 13 & 8.7 & 8.7 & 54.7 \\
\hline$>10$ years & 68 & 45.3 & 45.3 & 100.00 \\
\hline Total & 150 & 100 & & \\
\hline \multicolumn{5}{|l|}{ Marital Status } \\
\hline Married & 101 & 67.3 & 67.3 & 67.3 \\
\hline Single & 49 & 32.7 & 32.7 & 100.00 \\
\hline Total & 150 & 100 & & \\
\hline \multicolumn{5}{|l|}{ Age } \\
\hline 21-25years & 42 & 28 & 28 & 28 \\
\hline 26-30years & 38 & 25.3 & 25.3 & 53.3 \\
\hline 31-40years & 46 & 30.7 & 30.7 & 84 \\
\hline 41-50years & 21 & 14 & 14 & 98 \\
\hline$>50$ years & 3 & 2 & 2 & 100.00 \\
\hline Total & 150 & 100 & & \\
\hline
\end{tabular}

Source: Primary Data

\section{Calculation of Path Analysis}

This study's path analysis model uses two independent variables as exogenous variables and one dependent variable as an endogenous variable. The exogenous variables are leadership $\left(\mathrm{X}_{1}\right)$ and job motivation $\left(X_{2}\right)$, while the endogenous variable is nursing performance $(\mathrm{Y})$.

The equation structure of the path diagram model $\left(Y=\rho \mathrm{yx}_{1} \mathrm{X}_{1}+\operatorname{\rho yx}_{2} \mathrm{X}_{2}+\varepsilon\right)$ could identify the causal relationship between these variables. Overall, there are three path coefficients, including 1) path coefficient on the effect of leadership on nursing performance $\left.\left(\rho \mathrm{yx}_{1} \mathrm{X}_{1}\right) ; 2\right)$ path coefficient on the effect of job motivation on nursing performance $\left(\rho \mathrm{yx}_{2} \mathrm{X}_{2}\right)$; and 3 ) path coefficient on the effect of other variables on nursing performance ( $\rho y \varepsilon$. Furthermore, the effect of exogenous variables on endogenous variables and the significance test of structural equation models were calculated simultaneously 
Table 2. Distribution of Respondents' Response.

\begin{tabular}{|c|c|c|c|c|c|c|c|}
\hline Variable & Dimension & $\begin{array}{c}\text { Strongly } \\
\text { disagree } \\
\text { (1) }\end{array}$ & $\begin{array}{l}\text { Disagree } \\
\text { (2) }\end{array}$ & $\begin{array}{c}\text { Quite } \\
\text { Disagree } \\
\text { (3) }\end{array}$ & $\begin{array}{l}\text { Agree } \\
\text { (4) }\end{array}$ & $\begin{array}{c}\text { Strongly } \\
\text { Agree } \\
\text { (5) }\end{array}$ & Total \\
\hline \multirow{4}{*}{$\begin{array}{l}\text { Leadership } \\
\text { role }\end{array}$} & Role model & $\begin{array}{l}13.9 \% \\
(125)\end{array}$ & $\begin{array}{r}14 \% \\
(126)\end{array}$ & $\begin{array}{l}8.6 \% \\
(77)\end{array}$ & $\begin{array}{c}28.1 \% \\
(253)\end{array}$ & $\begin{array}{l}35.4 \% \\
(319) \\
\end{array}$ & $100 \%$ \\
\hline & Pioneer & $\begin{array}{l}14.8 \% \\
(111) \\
\end{array}$ & $\begin{array}{l}19.2 \% \\
(144) \\
\end{array}$ & $\begin{array}{l}10 \% \\
(75) \\
\end{array}$ & $\begin{array}{l}34 \% \\
(255) \\
\end{array}$ & $\begin{array}{r}22 \% \\
(165) \\
\end{array}$ & $100 \%$ \\
\hline & Coordinator & $\begin{array}{l}2.1 \% \\
(16)\end{array}$ & $\begin{array}{l}3.1 \% \\
(23)\end{array}$ & $\begin{array}{c}5.5 \% \\
(41)\end{array}$ & $\begin{array}{l}44.1 \% \\
(331)\end{array}$ & $\begin{array}{l}45.2 \% \\
(339)\end{array}$ & $100 \%$ \\
\hline & Advocator & $\begin{array}{l}5.6 \% \\
(50) \\
\end{array}$ & $\begin{array}{c}10.1 \% \\
(91) \\
\end{array}$ & $\begin{array}{c}7.7 \% \\
(69) \\
\end{array}$ & $\begin{array}{l}42.7 \% \\
(384) \\
\end{array}$ & $\begin{array}{r}34 \% \\
(306) \\
\end{array}$ & $100 \%$ \\
\hline \multirow{4}{*}{$\begin{array}{l}\text { Job } \\
\text { motivation }\end{array}$} & $\begin{array}{l}\text { Physiological } \\
\text { Needs }\end{array}$ & $\begin{array}{l}20.4 \% \\
(92)\end{array}$ & $\begin{array}{l}22.9 \% \\
(103)\end{array}$ & $\begin{array}{c}11.6 \% \\
(52)\end{array}$ & $\begin{array}{c}19.1 \% \\
(86)\end{array}$ & $\begin{array}{l}26 \% \\
(117)\end{array}$ & $100 \%$ \\
\hline & Security Needs & $\begin{array}{l}5 \% \\
(30)\end{array}$ & $\begin{array}{l}11 \% \\
(66)\end{array}$ & $\begin{array}{c}10.8 \% \\
(65)\end{array}$ & $\begin{array}{c}38.5 \% \\
(231)\end{array}$ & $\begin{array}{l}34.7 \% \\
(208)\end{array}$ & $100 \%$ \\
\hline & $\begin{array}{l}\text { Appreciation } \\
\text { Needs }\end{array}$ & $\begin{array}{l}6.2 \% \\
(28)\end{array}$ & $\begin{array}{c}16.9 \% \\
(76)\end{array}$ & $\begin{array}{c}11.3 \% \\
(51)\end{array}$ & $\begin{array}{c}42.4 \% \\
(191)\end{array}$ & $\begin{array}{l}23.1 \% \\
(104)\end{array}$ & $100 \%$ \\
\hline & $\begin{array}{l}\text { Self-actualization } \\
\text { Needs }\end{array}$ & $\begin{array}{l}2 \% \\
(6)\end{array}$ & $\begin{array}{c}6.3 \% \\
(19)\end{array}$ & $\begin{array}{c}14.7 \% \\
(44)\end{array}$ & $\begin{array}{c}55.3 \% \\
(166)\end{array}$ & $\begin{array}{c}21.7 \% \\
(65)\end{array}$ & $100 \%$ \\
\hline \multirow{6}{*}{$\begin{array}{l}\text { Staff } \\
\text { Performance }\end{array}$} & Clarity & $\begin{array}{l}6 \% \\
(36) \\
\end{array}$ & $\begin{array}{c}14.5 \% \\
(87)\end{array}$ & $\begin{array}{c}14.3 \% \\
(86)\end{array}$ & $\begin{array}{c}42.5 \% \\
(255)\end{array}$ & $\begin{array}{c}22.7 \% \\
(136)\end{array}$ & $100 \%$ \\
\hline & Assistance & $\begin{array}{l}4.7 \% \\
(21)\end{array}$ & $\begin{array}{c}13.3 \% \\
(60)\end{array}$ & $\begin{array}{c}12.9 \% \\
(58)\end{array}$ & $\begin{array}{r}36 \% \\
(162) \\
\end{array}$ & $\begin{array}{c}33.1 \% \\
(149)\end{array}$ & $100 \%$ \\
\hline & Incentive & $\begin{array}{l}2.7 \% \\
(16)\end{array}$ & $\begin{array}{c}9.3 \% \\
(56)\end{array}$ & $\begin{array}{c}9.8 \% \\
(59)\end{array}$ & $\begin{array}{c}43.5 \% \\
(261)\end{array}$ & $\begin{array}{c}34.7 \% \\
(208)\end{array}$ & $100 \%$ \\
\hline & Evaluation & $\begin{array}{l}2.7 \% \\
(16)\end{array}$ & $\begin{array}{c}10.3 \% \\
(62) \\
\end{array}$ & $\begin{array}{c}16.5 \% \\
(99)\end{array}$ & $\begin{array}{l}47.8 \% \\
(28.7) \\
\end{array}$ & $\begin{array}{l}22.7 \% \\
(136)\end{array}$ & $100 \%$ \\
\hline & Accuracy & $\begin{array}{l}9 \% \\
(4)\end{array}$ & $\begin{array}{l}7.9 \% \\
(35)\end{array}$ & $\begin{array}{c}13.6 \% \\
(61)\end{array}$ & $\begin{array}{c}60.4 \% \\
(272)\end{array}$ & $\begin{array}{c}17.3 \% \\
(79)\end{array}$ & $100 \%$ \\
\hline & Social life & $\begin{array}{l}2.9 \% \\
(13)\end{array}$ & $\begin{array}{c}9.8 \% \\
(44)\end{array}$ & $\begin{array}{c}12.9 \% \\
(58)\end{array}$ & $\begin{array}{l}44.4 \% \\
(200)\end{array}$ & $\begin{array}{l}30 \% \\
(135)\end{array}$ & $100 \%$ \\
\hline
\end{tabular}

Based on Table 3, the correlation coefficient between the effect of leadership and job motivation on nursing performance was 0.748 . It shows that the effect of leadership and job motivation on nursing performance was strong.

The determination coefficient of $R$ square or $R^{2}{ }_{y \times 2 \times 1}$ equals to 0.559 or $55.9 \%$. It means that a $55.9 \%$ variation in nursing performance could be further defined by variations in the effect of leadership and job motivation. In other words, the effect of leadership and job motivation on nursing performance was $55.9 \%$. Meanwhile, the effect of other variables that this study did not examine was $44.1 \%$.
Table 3. Path Analysis of the Effect of Head's leadership and Nurses' Job Motivation on Nursing Performance.

\begin{tabular}{ccccc}
\hline Model & $\mathbf{R}$ & $\begin{array}{c}\mathbf{R} \\
\text { Square }\end{array}$ & $\begin{array}{c}\text { Adjust } \mathbf{R} \\
\text { Square }\end{array}$ & $\begin{array}{c}\text { Std } \\
\text { Error }\end{array}$ \\
\hline 1 & .748 & .559 & .553 & 6.576
\end{tabular}

Source: Primary data

The results indicate that the path coefficient of non-examined variables on nursing performance ( $\left.{ }_{\mathrm{Y}_{\varepsilon}}\right)$ was 0.664 . Based on the regression equation, the coefficient of the effect of leadership on nursing performance $\left(\rho \mathrm{x}_{1} \mathrm{X}_{1}\right)$ was at 0.473 . While, the coefficient of the effect of job motivation on nursing performance $\left(\rho \mathrm{y}_{2} \mathrm{X}_{2}\right)$ was at 0.745 . Overall, the structural equation model would beÝ= 
$9.157+0,473 X_{1}+0,745 X_{2}+0,664 \varepsilon$.

Based on the $F$ test (ANOVA), the path coefficient shows two independent variables that affected the dependent variable. Thus, the path analysis results could be made into structural equations as in the path diagram model.

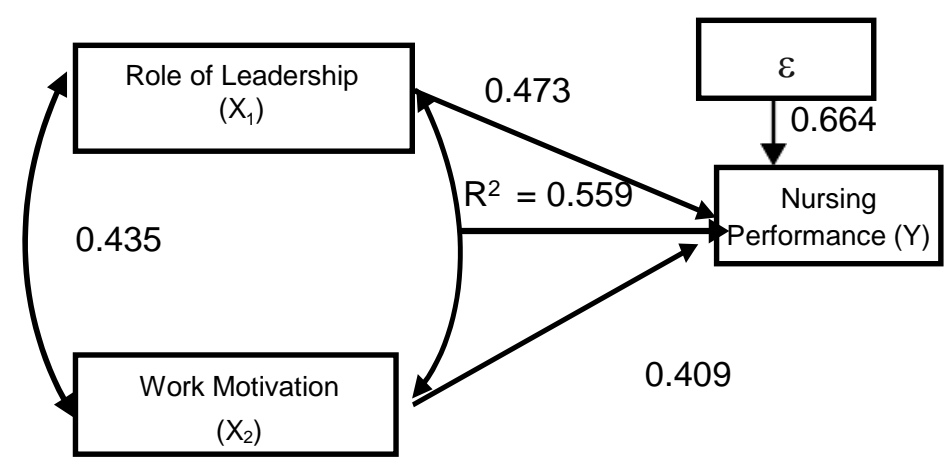

Figure 1.

Results of Structure Diagram Model

Direct, Indirect, and Total Effect of

\section{Leadership on Nursing Performance}

The score of the direct effect of leadership $\left(\mathrm{X}_{1}\right)$ on nursing performance $(\mathrm{Y})$ was $0.473 \times 0.473$, which equals to $22.4 \%$. Meanwhile, the score of the indirect effect of leadership $\left(\mathrm{X}_{1}\right)$ on nursing performance $(\mathrm{Y})$ through job motivation $\left(\mathrm{X}_{2}\right)$ was $0.473 \mathrm{x}$ $0.435 \times 0.409$, which equals to $8.4 \%$. Thus, the total score of the effect of leadership $\left(\mathrm{X}_{1}\right)$ on nursing performance $(\mathrm{Y})$ was at $30.8 \%$. In conclusion, leadership could determine nursing performance as much as $30.8 \%$.

\section{Effect of Job Motivation on Nursing Performance}

The score of the direct effect of job motivation $\left(\mathrm{X}_{2}\right)$ on nursing performance $(\mathrm{Y})$ was $0.409 \times 0.409$, which equals to $16.7 \%$. Meanwhile, the score of the indirect effect of job motivation $\left(X_{2}\right)$ on nursing performance $(\mathrm{Y})$ through leadership $\left(\mathrm{X}_{1}\right)$ was $0.409 \times 0.435 \times 0.473$, which equals to $8.4 \%$. Thus, the total score of the effect of job motivation $\left(\mathrm{X}_{2}\right)$ on nursing performance (Y) was at $25.1 \%$. In other words, job motivation could contribute to nursing performance by $25.1 \%$.
This study's discussion is based on the causality relationship of leadership and job motivation as antecedent variables (a cause) and nursing performance as a consequent variable (a phenomenon or consequence). With this idea, the discussion only includes analyzing both the partial and joint effects of leadership and job motivation on nursing performance.

The results of this study indicate that leadership affected nursing performance as much as $42.4 \%$. This study found a meaningful causal relationship (causeeffect) of leadership and nursing performance. In other words, if leadership is improved, nursing performance will simultaneously increase too.

The theoretical approach by Covey (2005) explains that leadership is a proactive effort to strengthen actual values and potencies of people reflected on four leadership roles, namely role model, pioneer, coordinator, and advocator. The results show that leaders as a pioneer had a dominant response from the respondents. Leadership is expected to help give stimulus on carrying, planning, and explaining tasks. It also aims to give employees the same view of the hospital's 
vision and mission and carry out every mandated task (Covey, 2005).

The respondents argued leadership could provide self-reflection on a good leader's attitudes and behaviors in performing and completing tasks. As leadership is considered as a pioneer, every leader can be the one who initiates to give an example of behaving or acting following the norms, ethics, and SOPs at the Indonesian Red Cross Hospital Bogor.

Table 4. Summary of Direct, Indirect, Total, and Joint Effects.

\begin{tabular}{|c|c|c|c|c|c|c|}
\hline \multirow{3}{*}{$\begin{array}{l}\text { Effect of } \\
\text { Variable }\end{array}$} & \multirow{3}{*}{$\begin{array}{c}\text { Path } \\
\text { Coefficient }\end{array}$} & \multicolumn{4}{|c|}{ Causal Effect (\%) } & \multirow[b]{3}{*}{$\begin{array}{l}\text { Joint } \\
\text { Effect }\end{array}$} \\
\hline & & \multirow[b]{2}{*}{ Direct } & \multicolumn{2}{|c|}{ Indirect } & \multirow[b]{2}{*}{ Total } & \\
\hline & & & $\begin{array}{c}\text { Through } \\
X_{1}\end{array}$ & $\begin{array}{c}\text { Through } \\
\mathrm{X}_{2}\end{array}$ & & \\
\hline $\mathrm{X}_{1} \rightarrow$ & 0.473 & $22.4 \%$ & - & $8.4 \%$ & $30.8 \%$ & - \\
\hline $\mathrm{X}_{2} \rightarrow \quad \mathrm{Y}$ & 0.409 & $16.7 \%$ & $8.4 \%$ & - & $25.1 \%$ & - \\
\hline$\varepsilon \rightarrow Y$ & 0.664 & $44.1 \%$ & - & - & - & $55.9 \%$ \\
\hline
\end{tabular}

This study's results are in line with the results of the research conducted by Putra (2013). He found that leadership affected employees' performance, as indicated by the value of $\beta=0.388$. If leadership increases, employees' performance will increase positively (Putra, 2013). The same thing is found in the research conducted by Wiranata (2011). The correlation value of leadership and employees' performance was at 0.73 , meaning a strong relationship between leadership and employees' performance.

Similarly to this study's findings, Isneini (2017) found that an instructional leadership style could complete nursing documentation at $79.8 \%$, while a consultative leadership style had complete documentation at $81.8 \%$. Moreover, the participative leadership style could document complete nursing care at $85.3 \%$. The delegation leadership style could complete documentation at $83.7 \%$ (Halimatussakdiah, Ampera and Isneini, 2015).

In line with this study's results, Sari (2019) discovered no significant relationship of head's leadership style and nursing performance in the inpatient room of the GMIM Pancaran Kasih Manado Hospital. It can be said that the leadership style cannot be ascertained because each head of the room had a different way to organize and direct his subordinates. Further analysis of leadership style's effect can be done when the heads use a democratic, participatory, or autocratic leadership style (Gannika and Buanasasi, 2019).

This present study pointed out that leadership had the lowest value among the other dimensions. The head's leadership could be seen from their initiative, characteristics, and competencies that the nurses could emulate. Leaders can also give nurses trust to perform their tasks.

The partial effect of job motivation on nursing performance at the hospital was $37.80 \%$. The significant effect indicates a meaningful causal relationship (causeeffect) between job motivation and nursing performance. In other words, job motivation will improve, so will nursing performance. A safe and conducive working environment and friendly colleagues inside or outside the hospital can improve job motivation (Finarti, Bachri and Arifin, 2016).

With similar findings, Putra (2013) found that motivation affected employees' performance as indicated by the value of $\beta$ $=0.168$, meaning that motivation and employees' performance will increase 
simultaneously. Motivation could be seen from employees' needs for achievement, patience, and honesty in facing workplace problems, unyielding attitude, and resilience towards failure (Putra, 2013).

The most desired dimension of job motivation was motivation to achieve good performance. The dimension of physiological needs has the lowest value among the other dimensions, including daily recreation needs. When nurses feel bored, recreational activities might refresh and encourage them to perform better at work. Physiological needs may improve employees' productivity, efficiency, and effectiveness to achieve organizational goals. It avoids failure in work reporting an unexpected absence and substituting employees by the organization or voluntarily. When employees resign, organizations must spend resources recruiting, training, and developing replacements (Jason et al., 2011).

Fulfilled physiological needs can provide good job motivation. Fulfilling the recreation needs can eliminate boredom and improve job motivation, resulting in better performance (Wirawan, 2015). Considering physiological needs is undoubtedly much more complicated than the quality of health services that focuses on patient safety (lqbal, Syed-abdul and Li, 2015). The quality of health services is a multidimensional concept, in which patient safety also needs to be improved to achieve better performance (Ghahramanian et al., 2017). The effect of leadership and job motivation on nursing performance was $55.9 \%$. The double hypothesis tests found a direct effect of leadership, and nursing performance $(22.4 \%)$ was greater than that of job motivation, which only reached 16.7\%. As four dimensions in leadership, such as role model, pioneer, coordinator, and advocator, could support leaders to be a good role model, nurses can get motivated to perform better.

Additionally, there was a partial effect of job motivation on nursing performance by $16.7 \%$. It indicates a meaningful causal relationship (cause-effect) between job motivation and nursing performance. The results also prove that motivation was one factor that affects the level of nursing performance at the Indonesian Red Cross Hospital Bogor.

Leaders' perceptions of organizational risks are primarily based on technological solutions to protect organizational assets and their belief that staffs usually adhere to the established organizational security policies (Phipps, Prieto and Verma, 2012). This indicates that leadership plays a role as a leveraging factor for the organization.

Leaders who perform themselves as pioneers will be able to strengthen employees' understanding of vision and mission. Staff with a high level of knowledge about the organization's vision and mission will affect motivation and inspiration to perform well at work (Darbi, 2012). A high level of knowledge about the organization's vision and mission will make staff think critically and pursue better work positions with increased enthusiasm and innovation (Orhan, Erdoğan and Durmaz, 2014). Leadership could construct values that will undoubtedly help form an organizational culture to give a more significant contribution to staff and patient satisfaction (Barrow, 2019). Moreover, it also could increase staff involvement in their work. Strong hierarchical orientation and results-based options from organizational culture as good leadership outputs can improve hospital performance (Sopoh et al., 2018).

Apart from the results of analysis, this study still had some shortcomings. It suggests further research to reach more units of analysis at the hospital. 


\section{CONCLUSION}

Leadership and job motivation could affect the level of nursing performance. Leadership and job motivation could lead to a high nursing performance level at the Indonesian Red Cross Hospital Bogor. It is recommended that hospitals have to improve leadership by giving rewards to each head of the room and nurses to provide the best services to patients. It is important for the Indonesian Red Cross Hospital Bogor to always simultaneously improve the head's leadership by providing an in-depth leadership program to strengthen understanding of vision and mission and evaluating their performance every year to improve their performance.

\section{CONFLICT OF INTEREST}

The authors declared that there was no conflict of interest in this study.

\section{REFERENCES}

Ady, F. and Wijono, D. (2013) 'Pengaruh Motivasi Kerja terhadap Kinerja Karyawan', Jurnal Maksipreneur: Manajemen, Koperasi, dan Entrepreneurship, 2(2), pp. 101-112. doi: 10.30588/jmp.v2i2.278.

Barrow, K. (2019) Organizational Culture Change in The United States Government and its Application in State and Local Public Health Agencies: A Literature Review. Nebraska.

Covey, S. R. (2005) The 8th Habit Melampaui Efektivitas, Menggapai Keagungan. Jakarta: Gramedia Pistaka Utama.

Creswell, J. W. (2015) Penelitian Kualitatif \& Desain Research Memilih di Antara Lima Pendekatan. Edited by A. L. Lazuardi. Yogyakarta: Pustaka Pelajar.

Darbi, W. P. K. (2012) 'Of Mission and Vision Statements and Their Potential Impact on Employee Behaviour and Attitudes: The Case of
A Public But Profit-Oriented Tertiary Institution', International Journal of Business and Social Science, 3(14), pp. 95-109.

Fajrianti, K. N. and Muhtadi, A. (2017) 'Review Artikel: Peningkatan Mutu Pelayanan Kesehatan Di Rumah Sakit Dengan Six Sigma', Farmaka, 15(3), pp. 111-122.

Finarti, D. R., Bachri, A. A. and Arifin, S. (2016) 'Hubungan Gaya Kepemimpinan, Motivasi, Stres Kerja dengan Kinerja Perawar', Jurnal Berkala Kesehatan, 1(2), pp. 115120. doi: 10.20527/jbk.v1i2.3150.

Gannika, L. and Buanasasi, A. (2019) 'Hubungan Gaya Kepemimpinan Kepala Ruangan Dengan Kinerja Perawat Di Ruang Rawat Inap Rumah Sakit GMIM Pancaran Kasih Manado', Jurnal Keperawatan, 7(1), pp. 1-8.

Ghahramanian, A. et al. (2017) 'Quality of healthcare services and its relationship with patient safety culture and nurse-physician professional communication', Health Promotion Perspectives, 7(3), pp. 168-174. doi: 10.15171/hpp.2017.30.

Gunawan, A. H. (2016) 'Analisis Kebutuhan Tenaga Perawat Unit Pelayanan Intensif Berdasarkan Beban Kerja dan Kompetensi di Unit Pelayanan Intensif Rumah Sakit Dr Oen Solo Baru Tahun 2015', Jurnal ARSI, 2(2), pp. 98-114.

Halimatussakdiah, Ampera, M. and Isneini (2015) 'The Correlation Between A Supervision Competence And A Conflict Management Style of Head of Nursing Department in Government Hospital In Banda Aceh', Journal Of Healthcare Technology And Medicine, 1(1). doi: 10.33143/jhtm.v1i1.1.

Hartono, B. et al. (2019) 'Pengaruh Sistem Remunerasi Terhadap Motivasi Kerja, Kepuasan Kerja dan Dampaknya Terhadap Kinerja Perawat di RS Paru Gunawan Tahun 2018', Jurnal Keperawatan Muhammadiyah, 4(2), pp. 24-30.

Hayat (2014) 'Kosep Kepemimpinan Dalam Reformasi Birokrasi: Aktualisasi Pemimpin Dalam Pelayanan Publik 
Menuju Good Governance', Jurnal Borneo Administrator, 10(1), pp. 5984.

Indriyati and Hayat (2015) 'Peranan Perawat dalam kerangka kinerja pelayanan publik beerdasarkan Undang-Undang Keperawatan', Jurnal Transormasi Administrasi, 5(1), pp. 828-845.

lqbal, U., Syed-abdul, S. and Li, Y. C. (2015) 'Improving quality of care and patient safety as a priority', International Journal for Quality in Health Care, 27(5), p. 335. doi: 10.1093/intqhc/mzv066.

Jabeen, R. (2016) 'The 7 Habits of Highly Effective People', Texila International Journal Of Nursing, Special Ed, pp. $1-5$.

doi: 10.21522/tijnr.2015.02.01.art023.

Jason A. et al. (2011) 'What is Organizational Behavior?', in Organizational Behavior: Improving Performance and Commitment in the Workplace. McGrow-Hill: New York.

Kuncoro, E. A. (2007) 'Analisis Pengaruh Lingkungan terhadap Modal Intelektual Organisasi', The Winners, 8(2), pp. 165-183. doi: 10.21512/tw.v8i2.738.

Linawati and Suhaji (2012) 'Pengaruh Motivasi, Kompetensi, Kepemimpinan, dan Lingkungan Kerja Terhadap Kinerja Karyawan (Studi Pada PT. Herculon Carpet Semarang)', Jurnal Kajian Akuntansi dan Bisnis, 1(1), pp. 1-14.

Newig, J. and Koontz, T. M. (2014) 'Multilevel governance, policy implementation and participation: The EU's mandated participatory planning approach to implementing environmental policy', Journal of European Public Policy, 21(2), pp. 248-267.

doi: 10.1080/13501763.2013.834070.

Orhan, G., Erdoğan, D. and Durmaz, V. (2014) 'Adopting Mission and Vision Statements by Employees: The Case of TAV Airports', in Procedia - Social and Behavioral Sciences, pp. 251262.

doi:

10.1016/j.sbspro.2014.09.051.

Paramita, P. D. (2011) 'Gaya Kepemimpinan (Style Of Leadership)
Yang Efektif dalam Suatu Organisasi, Majalah Ilmiah Universitas Pandanaran, 9(21).

Pepo, A. A. H. and Yulia, N. (2015) 'Kelengkapan Penulisan Diagnosa Pada Resume Medis Terhadap Ketepatan Pengkodean Klinis Kasus Kebidanan', Jurnal Manajemen Informasi Kesehatan Indonesia, 3(2), pp. 74-80. doi: 10.33560/.v3i2.88.

Phipps, S. T. A., Prieto, L. C. and Verma, S. (2012) 'Holding the Helm: Exploring the Influence of Transformational Leadership on Group Creativity, and the Moderating Role of Organizational Learning Culture', Journal Of Organizational Culture, Comminications and Conflict, 16(2), pp. 145-156.

Putra, N. P. (2013) Pengaruh Kepemimpinan, Motivasi, Lingkungan Kerja, Dan Disiplin Kerja Terhadap Kinerja Karyawan Pada PT. Indonesia Power Semarang. Undergraduate Thesis. Dian Nuswantoro Semarang University.

Robbins, S. P. (1994) Teori Organisasi: struktur, Desain dan Aplikasi. Jakarta: Arcan.

Robbins, S. P. (2001) Perilaku Organisasi : Konsep, Kontroversi, Aplikasi. 8th edn. Jakarta: Prenhallindo.

Robbins, S. P. (2006) Perilaku Organisasi. Jakarta: Gramedia Pustaka Utama.

Sopoh, G. E. et al. (2018) 'Analysis of the organizational culture at a hospital in Benin', Journal of Hospital Administration, 7(1), p. 35 . doi: 10.5430/jha.v7n1p35.

Sugiyono (2011) 'Populasi, Sampel, Pengujian Normalitas Data', in Statistika Untuk Penelitian. Bandung: CV. Alfabeta Bandung.

Tampubolon, B. D. (2007) 'Analisis Faktor Gaya Kepemimpinan Dan Faktor Etos Kerja Terhadap Kinerja Pegawai Pada Organisasi Yang Telah Menerapkan SNI 19-9001-2001', Jurnal Standarisasi, 9(3), pp. 106 115.

Tri Sasongko, A. D. J. (2016) 'Pengaruh Gaya Kepemimpinan Situasional, Kompensasi Dan Motivasi Terhadap Kinerja Karyawan Pada PT. Bank Rakyat Indonesia (Persero), Tbk. 
Cabang Nganjuk', Revitalisasi Jurnal Ilmu Manajemen, 5(1), pp. 44-59.

Usman, I. and Ardiyana, M. (2017) 'Lean Hospital Management, Studi Empirik pada Layanan Gawat Darurat', Jurnal Manajemen Teori dan Terapan / Journal of Theory and Applied Management, 10(3), pp. 257-270. doi: 10.20473/jmtt.v10i3.7089.

Vermasari, A., Masrul, M. and Yetti, $\mathrm{H}$. (2019) 'Analisis Implementasi Standar Pelayanan Minimal (SPM) Di Instalasi Gawat Darurat (IGD) Rsu Mayjen $\mathrm{Ha}$ Thalib Kabupaten Kerinci', Jurnal Kesehatan Andalas, 8(2), pp. 275-294. doi: 10.25077/jka.v8i2.1002.

Warella, Y., Rachmawati, E. and Hidayat, Z. (2006) 'Pengaruh Motivasi Kerja, Kemampuan Kerja dan Gaya Kepemimpinan Terhadap Kinerja Karyawan Pada Badan Kesatuan
Bangsa dan Perlindungan Masyarakat Propinsi Jawa Tengah', Dialogue, 3(1).

Wibowo, S. (2015) 'Analisis Perbandingan Kineja Keuangan PerBankkan Syariah dengan Metode CAMEL di ASEAN (Studi Komparatif: Indonesia, Malaysia, Thailand)', Jurnal Riset Ekonomi dan Manajemen, 15(1), pp. 136-153.

Wiranata, A. A. (2011) 'Pengaruh Kepemimpinan Terhadap Kinerja dan Stres Karyawan (Studi Kasus: CV. Mertanadi) Anak Agung Wiranata', Management, 15(2), pp. 155-160.

Wirawan, F. (2015) 'Pengaruh gaya kepemimpinan, komunikasi organisasi dan motivasi kerja terhadap kinerja karyawan', Diponegoro Journal of Management, 4(2), pp. 1-12. 